\title{
Response to Tobacco Free Ireland 2025: SimSmoke prediction for the end-game
}

\author{
Frank Houghton', Diane O' Doherty', Derek Mclnerney', Bruce Duncan²
}

\section{Dear Editors,}

$\mathrm{Li}$ and colleagues are to be commended for their recent $\operatorname{article~}^{1}$ that uses the SimSmoke simulation model to predict that Ireland will fail to meet its target of being smoke free by 2025 , which it defines as having a smoking rate of less than $5 \%^{2}$. It is hoped that, despite the limitations inherent in any predictive computer modelling, their quantitative analysis of the forthcoming failure for Ireland to meet its own targets will spur the Irish Government into assertively tackling the tobacco epidemic in a more robust manner. Smoking remains a significant issue in Ireland, with The Tobacco Atlas estimating 5600 deaths per year from tobaccoinduced diseases and an economic cost of $€ 2826$ million associated with smoking for Ireland ${ }^{3}$.

The present response aims to elaborate further on some of the issues raised by Li et al. ${ }^{1}$, and to outline some areas of further vulnerability in Ireland's attempts to reduce smoking.

$\mathrm{Li}$ et al. noted the higher smoking rate of Polish immigrants in Ireland ${ }^{4}$. The Poles are Ireland's largest group of non-Irish nationals ${ }^{5}$. However, it is perhaps also important to acknowledge the potential relevance of the high rate of smoking in Lithuania ${ }^{3}$. Although data is lacking on smoking prevalence among Lithuanian immigrants in Ireland, smoking rates in Lithuania are significantly higher than in Ireland (38.1\% among males and $22.2 \%$ among females), with Lithuanians being Ireland's third largest minority. It should be noted that a basic single ticket from Dublin to either Poland or Lithuania can be purchased routinely from a budget airline company for only $€ 19.99$. Thus, immigrant groups have potentially easy access in their country of origin to cigarettes and tobacco at a fraction of the price in Ireland and without the plain packaging requirements mandated by Irish legislation. One development that is not considered in the SimSmoke simulation is 'Brexit'; the United Kingdom's imminent exit from the European Union. It is noteworthy that repeated investigations into the illicit tobacco trade in Ireland have highlighted the significance of its magnitude ${ }^{6}$. A government survey in 2016 estimated that the illicit cigarette trade in Ireland exceeded 20 million packets per year, representing approximately 5 packets for each man, woman and child ${ }^{7}$. It should be noted that prosecutions related to illicit tobacco trade and smuggling in Ireland are extremely rare $^{6}$, despite the high volume of such products consumed ${ }^{6}$. Although it must be acknowledged that tobacco industry assessments of the scale of the illicit tobacco trade consistently over-estimate the size of the problem $^{8-11}$, it is still estimated that illicit cigarettes constitute $4.9 \%$ of all manufactured cigarettes smoked in Ireland ${ }^{11}$.

The potential impact of 'Brexit' is crucial given that previous investigations ${ }^{12}$ on the impact of smuggling and the cross-border trade with Northern Ireland, which minimised this issue, were conducted in an era of large-scale ceasefires, political progress, a functioning Northern Ireland Assembly, and an open border.
AFFILIATION

1 Limerick Institute of Technology, Limerick, Ireland 2 Hauora Tairawhiti, Gisborne, New Zealand

CORRESPONDENCE TO Frank Houghton. Limerick Institute of Technology, Limerick, Ireland. Email: frank. houghton@lit.ie

KEYWORDS

Ireland, SimSmoke, tobacco end-game, paramilitarism

Received: 28 September 2018 Revised: 22 November 2018 Accepted: 21 December 2018 
The prospect of border controls between Northern Ireland and the Republic of Ireland may foster political instability and paramilitary activity, particularly in the context of the current impasse in Northern Ireland politics. It is important to note that the illicit tobacco trade has long been linked to paramilitary activity, including that of groups in Ireland ${ }^{13-15}$ and elsewhere ${ }^{16}$. Paramilitary groups often have the infrastructure, networks, resources and the drive to develop production and importation of illicit goods, including cigarettes $^{15-16}$. Concern about illicit tobacco products has already been raised among many retailers in the border region $^{17}$, a contested area with a long history of lawlessness and ineffective policing ${ }^{18-19}$.

The verdict of the SimSmoke simulation of Ireland's impending failure to reach its 2025 Smoke Free target is undoubtedly correct. However, the simulation may, in fact, significantly over-estimate the future decrease in tobacco consumption rates in Ireland. One determining factor for such an over-estimation arises from Ireland's population becoming increasingly diverse, with some immigrant groups having relatively easy access to cheaper cigarettes in their country of origin. A second factor for an over-estimation in the decrease in tobacco consumption is the potential growth of political instability and paramilitarism as a consequence of 'Brexit' that may result in an increase in the illicit cigarette trade.

\section{REFERENCES}

1. Shasha Li, David Levy, Luke Clancy. Tobacco Free Ireland 2025: SimSmoke prediction for the end game. Tobacco Prevention \& Cessation 2018; 4(June):23. doi:10.18332/tpc/91427

2. Tobacco Policy Review Group. Tobacco Free Ireland. https://health.gov.ie/wp-content/uploads/2014/03/ TobaccoFreeIreland.pdf. Published October, 2013. Accessed June 25, 2018.

3. Drope J, Schluger N, Cahn Z, Drope J, Hamill S, Islami F, Liber A, Nargis N, Stoklosa M. The Tobacco Atlas. https:// tobaccoatlas.org/wp-content/uploads/2018/03/TobaccoAtlas_6thEdition_LoRes_Rev0318.pdf. Published March, 2018. Accessed June 25, 2018.

4. Kabir Z, Clarke V, Keogan S, Currie LM, Zatonski W, Clancy L. Smoking characteristics of Polish immigrants in Dublin. BMC Public Health. 2008;8(1): 428. doi:10.1186/1471-2458-8-428.

5. Central Statistics Office. Press Statement Census 2016 Results Profile 7 - Migration and Diversity.https://www.cso.ie/ en/csolatestnews/pressreleases/2017pressreleases/pressstatementcensus2016resultsprofile7-migrationanddiversity/. Published September, 2017. Accessed June 25, 2018.

6. Grant Thornton. Illicit Trade 2015-2016: Implications for the Irish economy. https://www.grantthornton.ie/ globalassets/1.-member-firms/ireland/insights/publications/grant-thornton---illicit-trade-2015-2016..pdf. Published May, 2016. Accessed June 25, 2018.

7. Revenue Commissioners. Illegal Tobacco Products Research Surveys. https://www.revenue.ie/en/corporate/documents/ research/illegal-tobacco-survey-2016.pdf. Published April, 2017. Accessed June 25, 2018.

8. Joosens L, Merriman D, Ross H, Raw M. The impact of eliminating the global illicit cigarette trade on health and revenue. Addiction. 2010 Sep;105(9):1640-9. doi: 10.1111/j.1360-0443.2010.03018.x.

9. Gilmore AB, Rowell A, Gallus S, Lugo A, Joossens L, Sims M. Towards a greater understanding of the illicit tobacco trade in Europe: a review of the PMI funded 'Project Star' report. Tobacco control 2014 May;23(e1):e51-61. doi: 10.1136/tobaccocontrol-2013-051240.

10. Stoklosa M, Ross H. Contrasting academic and tobacco industry estimates of illicit cigarette trade: evidence from Warsaw, Poland. Tobacco Control 2014 May;23(e1):e30-4. doi:10.1136/tobaccocontrol-2013-051099.

11. Joossens L, Lugo A, Vecchia C, Gilmore AB, Clancy L, Gallus S. Illicit cigarettes and hand-rolled tobacco in 18 European countries: a cross-sectional survey. 2014, 23(0): e17-e23. doi:10.1136/tobaccocontrol-2012-050644

12. Reed H. Tobacco Taxation, Smuggling \& Smoking in Ireland. https://www.drugsandalcohol.ie/18296/1/ Tobaccotaxationsmugglingandsmoking.pdf. Published October, 2011. Accessed June 25, 2018.

13. US Department of State. The Global Illicit Trade in Tobacco: A Threat to National Security. https://2009-2017.state.gov/ documents/organization/250513.pdf. Published December, 2015. Accessed June 25, 2018.

14. O'Riordan S. Special Report: Illegal cigarettes easily available in rural Cork areas. Irish Examiner. 17 th July 2016. https://www.irishexaminer.com/ireland/special-report-illegal-cigarettes-easily-available-in-rural-cork-areas-410616. html. Published, July 17, 2017. Accessed June 25, 2018.

15. de Sola D. Paramilitary Financing in Northern Ireland, 1969-1998: How Arms Deals, Crime, and International Networks Fueled the Troubles. Georgetown Security Studies Review 2018; 6(2):86-100.

16. Billingslea W. Illicit Cigarette Trafficking and the Funding of Terrorism. The Police Chief 2004;70(2):49-54. 
17. Retailers Against Smuggling. One in three retailers along the border concerned that Brexit will create a bigger market for smuggling along the border. http://www.retailersagainstsmuggling.ie/one-in-three-retailers-along-the-border-concernedthat-brexit-will-create-a-bigger-market-for-smuggling-along-the-border/. Published October 5, 2017. Accessed June 25, 2018.

18. Patterson H. Ireland's Violent Frontier. Basingstoke, Hampshire: Palgrave Macmillan; 2013.

19. Conway V. Policing Twentieth Century Ireland- A History of An Garda Síochána. London: Routledge; 2013.

CONFLICTS OF INTEREST

The authors have completed and submitted the ICMJE Form for Disclosure of Potential Conflicts of Interest and none was reported.

FUNDING

There was no source of funding for this research.

PROVENANCE AND PEER REVIEW

Not commissioned; internally peer reviewed. 